\title{
Effect of Using Solar Energy and Different Ventilation Rate on Production in Poultry Houses
}

\author{
Soliman Gad*, Mahmoud Abdel Rahman El-Shazly, Kamal Ibrahim Wasfy and Alaa Awny \\ Department of Agricultural Engineering Faculty of Agriculture, Zagazig, Zagazig University, Egypt \\ *Corresponding author's Email: s_gad1244@yahoo.com; ORCID: 0000-0002-2181-1457
}

Received: 24 Oct. 2019

Accepted: 01 Dec. 2019

\begin{abstract}
The main purpose of the present study was to find an alternative source for traditional energy to provide the energy requirements in the poultry industry. The present study was conducted in four poultry houses with different heating systems (solar and conventional) and ventilation rates located in El-Sharkia Governorate, Egypt, during June and July 2018. In this study, it was found that productivity increased by increasing the ventilation rate, where productivity reached $2.3 \mathrm{~kg}$ when using a solar heating system with a ventilation rate every two minutes. Productivity decreased in poultry houses with a conventional heating system and was $2 \mathrm{~kg}$ in ventilation rate every 2 minutes, and $1.8 \mathrm{~kg}$ in the ventilation rate every four minutes. The level of ammonia was also reduced with the ventilation rate every two minutes. Concentrations of ammonia ranged from $22 \mathrm{ppm}$ at ventilation rate every two minutes to $28 \mathrm{ppm}$ at the ventilation rate every four minutes. In addition, solar energy provided good levels of thermal requirements. It was demonstrated that solar energy as an alternative source to the conventional energy, is very efficient and can be applied on a large scale when combined with conventional electricity as a light source and within specified limits.
\end{abstract}

Key words: Energy balance, Poultry production, Solar heating system, Ventilation

\section{INTRODUCTION}

Following climate changes, high temperatures in summer and extreme cold in winter, as well as rising costs of conventional energy, there is increasing interest in renewable energy sources, especially solar energy among industrial and academic sectors.

High environmental temperature incur huge economic losses on the poultry industry due to reduced growth and laying performance of birds, and also cause concern about poultry welfare (El-Kholy et al., 2017).

Poultry are usually raised in barns, with short growth cycles suitable for the enclosed barn environment in the energy-intensive process. Broiler farms rely on ventilation and heating of barn to ensure the well-being and development of birds. Therefore, ventilation and heating control is the largest energy demand for chicken farms (Hamilton et al., 2016).

Poultry needs temperatures ranged from 26 to $35{ }^{\circ} \mathrm{C}$ and humidity levels between 60 to $75 \%$. The ventilation system is required for the disposal of polluting substances such as carbon dioxide produced by respiration and other gases emitted from poultry waste. Heat is an important factor affecting the quality of production and animal health. Recently, providing the optimal temperature for poultry houses required too much energy due to the remarkable changes in the environment and climate. High energy expense has led to higher overall costs of production in the poultry industry (Beker et al., 2004). Beker et al. (2004) found that ammonia in poultry houses lowers performance and may increase disease susceptibility. It has been suggested that ammonia should not exceed $25 \mathrm{ppm}$ in poultry houses. Ventilation is important to remove moisture, heat, organisms, ammonia and hydrogen sulfide. Ventilation also replenishes oxygen consumed by birds and gas brooders used to heat poultry building. Energy savings have become increasingly important due to climate change and rising energy prices. Nowadays, feed is the largest portion of the cost of poultry production (Tike, 2010). Fuel and electricity costs are still quite low compared with the cost of feed, however, it is expected that their share of total costs increases in the future.

The main objective of the present study was to use solar energy in poultry farms. 


\section{MATERIALS AND METHODS}

The experiments were performed in four identical poultry farms in El-Sharkia governorate, Egypt from June to July 2018. The altitude of the study area is $18 \mathrm{~m}$ and geographic coordinates of area are latitude $30^{\circ} 10^{\prime}$ to $31^{\circ} 19^{\prime} \mathrm{N}$, longitude $32^{\circ} 15^{\prime} \mathrm{E}$. One-hundred cobb500 chicks were used in every house. Chicks were delivered at the age of one-day-old and weight of 40-45 $\mathrm{g}$ and slaughtered after 35 days growing period. The chicks were high in vitality. The diet consisted of a starter $(3050 \mathrm{Kcal}$ $/ \mathrm{kg})$, grower $(3050 \mathrm{Kcal} / \mathrm{kg})$ and finisher feed $(2900 \mathrm{Kcal}$ $/ \mathrm{kg})$.

\section{Poultry house}

The houses were designed in a closed system. Modern poultry houses were made of or bricks and concrete with industrial ventilation and cooling system. Broiler house is heated mainly using renewable energy. The size of the houses was approximately $4 \mathrm{~m}$ in length, $2.5 \mathrm{~m}$ in width and $3 \mathrm{~m}$ in height (Figure 1), with a capacity of 100 birds. The average bird density was 10 $\mathrm{bird} / \mathrm{m}^{2}$. In present experiments, plastic pan feeders with a diameter of $30 \mathrm{~cm}$ (70 birds per pan), and bell drinker (50 birds/bell) were used.

\section{Ventilation system}

The farms were supplied with fans that drain the air from inside the farm to the outside. The fan engine model was 3165-00 manufactured in China (power: 90 watts, rotation speed: $300 \mathrm{rpm}$, engine: $220-240$ volts, $50-60 \mathrm{~Hz}$ ) and fan dimensions were $50 \times 50 \mathrm{~cm}$. The fan was installed from the side. The capacity of each fan was 4000 $\mathrm{m}^{3}$ of air/h with a flow rate of $4 \mathrm{~m}^{3}$ air $/ \mathrm{h} / \mathrm{kg}$ of live weight in summer. The fan had shutters that open when the fan was running and close by gravity when it was idle.

\section{Cooling system}

In this experiment, direct evaporative cooling systems were used. This system consisted of the cooling pad (dimensions: $60 \times 50 \mathrm{~cm}$; thickness: $10 \mathrm{~cm}$ ) and fan. The system has a 100 watts pump that pumped water from the water tank to the pad. There were also lines to return water to the tank.

\section{The heating system and power sources}

The traditional heating system in poultry houses used two sources of energy. The first source was fossil fuels such as petroleum or natural gas and the second source was electricity and an electric meter connected with each experimental unit to measure energy consumption. In the house, the electric heater has a power of up to $1500 \mathrm{~W}$. As shown in figure 2 , the solar heating system consisted of the three connected subsystems including solar thermal collector, thermal storage system and heat distribution system.

The dimensions of the typical flat-plate solar collector were $80 \times 120 \mathrm{~cm}$, with a thickness of $10 \mathrm{~cm}$. Absorber surface plate (dimensions: $95 \times 95 \mathrm{~cm}$ ) was painted with black color for increasing solar energy absorption. The absorber plate was welded with 12 horizontal copper pipes of $7 \mathrm{~mm}$ diameter (Thermal conductivity coefficient of $400 \mathrm{~W} / \mathrm{m}$. K), insulated body by fiberglass (Thermal conductivity coefficient of 0.04 $\mathrm{W} / \mathrm{m}$. K). In this design, the main energy storage system used was sensible heat storage. The heating system was equipped with a capacity of $300 \mathrm{~L}$ water and a $300 \mathrm{~W}$ pump. In the design of the solar heating unit, calculations were performed based on the maximum thermal requirements of the farm. The hot fluid inlet of the tank was fed by the water circulating from the thermal solar collector. The solar heating unit was manufactured locally from iron pipes connected to each other in an entry line and a water return line of $100 \times 100 \mathrm{~cm}$.

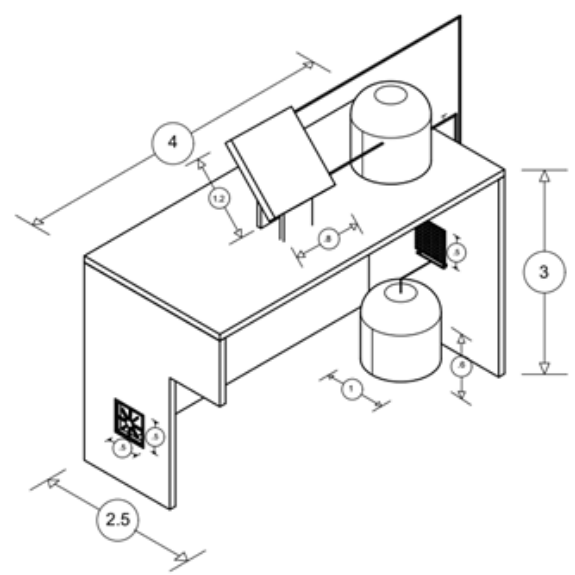

Figure 1. Poultry house with a solar collector

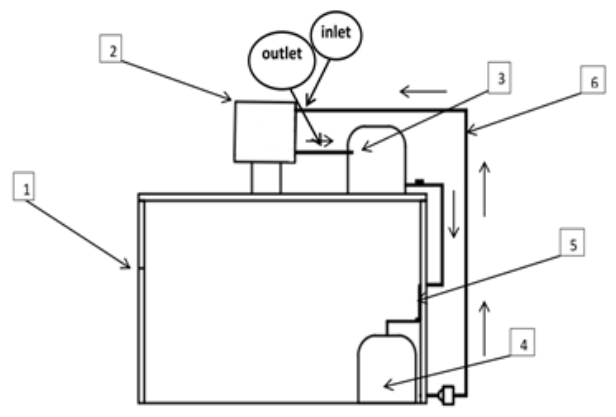

Figure 2. Poultry house components. 1. Door; 2. Solar collector; 3. Water storage tank; 4. Receiver tank; 5. Cooling pad; 6. Return line. 


\section{Experimental conditions}

House 1 was working with solar heating unit and ventilated every $2 \mathrm{~min}$. House 2 was working with a traditional heating system and ventilated every $2 \mathrm{~min}$. House 3 was equipped with solar heating unit and ventilated every 4 min and house 4 was working with a traditional heating system and ventilation rate of $4 \mathrm{~min}$.

\section{Thermal performance analysis of solar water heating system}

The basic parameter to consider was the efficiency of solar thermal collectors, defined as the ratio of the useful heat energy delivered to the solar energy flux incident on the collector aperture. Under steady-state conditions, the performance analysis can be measured and determined using the system analysis described Kalogirou (2004) as follows:

Solar energy available was obtained via the following equation: $Q=R A_{c}$

Where $\mathrm{Q}$ is solar energy available, $\mathrm{R}$ is solar radiation falling on collector surface $\left(\mathrm{W} / \mathrm{m}^{2}\right)$ and $\mathrm{A}_{\mathrm{c}}$ is the surface area of the solar collector $\left(\mathrm{m}^{2}\right)$.

Absorbed solar radiation $\left(\mathrm{Q}_{\alpha}\right)$ was calculated using the following equation:

$Q_{a}=R A_{c}(\alpha \tau)$

$\alpha=\alpha_{\text {max }}-0.00476 \exp [0.040(\theta-35)]$

$\tau=\tau_{\max }-0.00437 \exp [0.0936(\theta-30)]$

Where $\alpha \tau$ is optical efficiency of the solar collector (decimal), $\alpha$ is the effective absorption of the absorber surface (decimal), $\tau$ is the effectiveness of permeability of covered glass (decimal) and $\Theta$ is the solar incident angle on the tilted surface (degree).

Heat removal factor $\left(F_{R}\right)$ is a quantity that relates actual useful energy gain of a collector to useful gain and was calculated by the following equation:

$\mathrm{F}_{R}=\frac{m C_{P}\left(T_{f o}-T_{f i}\right)}{A c\left[R(\alpha \tau)-U o\left(T_{f i}-T_{a}\right)\right]}$

Where $\mathrm{m}$ is the mass flow rate of fluid $(\mathrm{kg} / \mathrm{s}), \mathrm{C}_{\mathrm{p}}$ is specific heat of water $\left(\mathrm{J}^{\mathrm{kg}} \mathrm{kg}^{-1} \cdot \mathrm{K}^{-1}\right), \mathrm{T}_{\mathrm{fo}}$ is outlet water temperature $\left({ }^{\circ} \mathrm{K}\right), \mathrm{T}_{\mathrm{fi}}$ is internal water temperature $\left({ }^{\circ} \mathrm{K}\right), \mathrm{T}_{\alpha}$ is ambient air temperature $\left({ }^{\circ} \mathrm{K}\right)$ and Uo is overall heat transfer coefficient $\left(\mathrm{W} / \mathrm{m}^{2} .{ }^{\circ} \mathrm{K}\right)$.

Useful heat gain $\left(\mathrm{Q}_{\mathrm{u}}\right)$ is defined as the maximum obtained energy of the solar collector when the water passed through the pipes of collector and determined using the follow equation:

$Q_{u}=F_{R}\left[Q_{a}-U_{o} A_{c}\left(T_{f i}-T_{a}\right)\right]$
Solar heat loss $\left(\mathrm{Q}_{\mathrm{L}}\right)$ is identified as the difference between absorbed solar energy and useful heat gain to the storage, as follow:

$Q_{L}=Q_{a}-Q_{u}$

The loss in the heat of the solar heater $\left(\mathrm{Q}_{\mathrm{L}}\right)$ can be also calculated by the following equation:

$Q_{L}=A_{c} U_{o}\left(T_{P}-T_{a}\right)$

Where $\mathrm{T}_{\mathrm{p}}$ is the mean temperature of the absorber plate $\left({ }^{\circ} \mathrm{K}\right)$.

Thermal efficiency of solar collector $\left(\eta_{0}\right)$ was calculated by the following equation:

$\eta_{o}=\frac{\mathrm{Qu}}{Q} \times 100$

The stored solar energy $\left(Q_{s}\right)$ in the storage tank can be determined by using the following equation:

$\mathrm{Q}_{s}=\mathrm{M}_{w} \mathrm{C}_{p}\left(\mathrm{~T}_{k e}-\mathrm{T}_{k b}\right) / \partial \tau$

Where $\mathrm{M}_{\mathrm{W}}$ is water mass $(\mathrm{kg}), \mathrm{T}_{\mathrm{ke}}$ is the water temperature in a storage tank at end of day $\left({ }^{\circ} \mathrm{K}\right), \mathrm{T}_{\mathrm{kb}}$ is the water temperature in the storage tank at beginning of day $\left({ }^{\circ} \mathrm{K}\right), \partial \tau$ is the time interval during which water circulates within the system (s).

The storage system efficiency $\left(\mathrm{n}_{s}\right)$ can be calculated as: $\eta_{s}=\frac{Q s}{Q_{u}} \times 100$

\section{Calculation of ventilation rate}

The air change rates were calculated by the following equation:

$\mathrm{QA}=$ live Wight $\times$ number of chicken $\times$ minimum ventilation rate $\left(\mathrm{m}^{3} / \mathrm{h}\right.$ per $\mathrm{Kg}$ live weight) (Arbor Acres, 2009). Where QA is the standard quantity of air to be removed

\section{Calculation of energy consumption Ventilation heat loss}

The heat loss caused by ventilation could be calculated by the following equation:

$$
\begin{aligned}
& P=c_{i} \rho_{i} q_{v}\left(T_{\text {in }}-T_{\text {out }}\right) \mathrm{P}=\text { ventilation heat loss } \\
& \mathrm{c}_{\mathrm{i}}=\text { air specific heat capacity, } 1,0(\mathrm{~kJ} / \mathrm{kg} \cdot \mathrm{K}) \\
& \rho_{\mathrm{i}}=\text { air density } \\
& \mathrm{q}_{\mathrm{v}}=\text { ventilation volume flow; } \\
& \mathrm{T}_{\text {in }}=\text { indoor temperature }(\mathrm{K}) \\
& \mathrm{T}_{\text {out }}=\text { outdoor temperature }(\mathrm{K})
\end{aligned}
$$

\section{Poultry heat production}

The broilers also produce heat, the sensible heat production was calculated by CIGR2002 method (Mannfros and Hautala, 2011), using following equation:

$$
p_{\text {sens }}=10.62 M^{0.75}\left[0.61(1+0.020(20-T))-2.28 .10^{-4} . T^{2}\right.
$$


Where $\mathrm{P}$ is heat power (W), $\mathrm{M}$ is broiler mass $(\mathrm{kg})$ and $\mathrm{T}$ is temperature $\left({ }^{\circ} \mathrm{C}\right)$.

\section{Measurements and determinations}

Air velocity Meter (TM-411/412/413/414) was used in the poultry houses to measure different macroclimate variables such as the dry-bulb air temperature (ventilated thermistor), wind speed, wet-bulb air temperature and air relative humidity (hygrometer).

\section{RESULTS AND DISCUSSION}

\section{Climate conditions}

One of the external climate factors affecting the internal environment of a poultry house is solar radiation. The maximum solar radiation value in June was 1119.2 $\mathrm{W} / \mathrm{m}^{2}$ in the afternoon, the radiation value at the beginning of the day was $220 \mathrm{~W} / \mathrm{m}^{2}$ and at the end of the day, the radiation intensity was $110 \mathrm{~W} / \mathrm{m}^{2}$ at 6 p.m. (Figure 3).
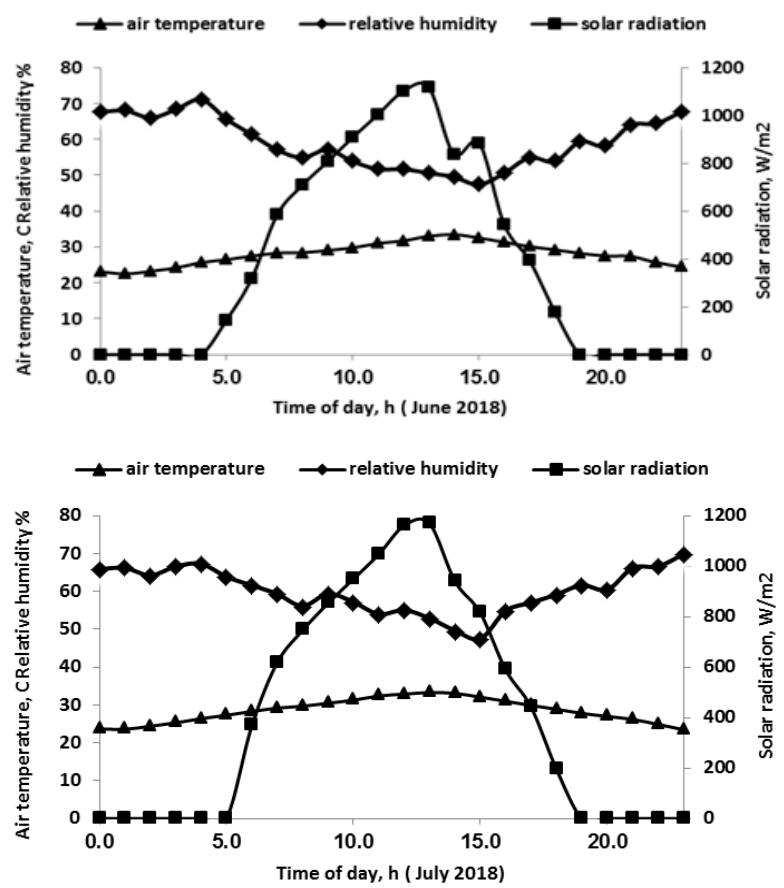

Figure 3. Distribution of solar radiation, air temperature, and relative humidity during June and July 2018 in ElSharkia Governorate, Egypt.

According to the Egyptian Meteorological Authority, in July, the maximum value of solar radiation at midday hours (12-1 p.m.) was $1166.6 \mathrm{~W} / \mathrm{m}^{2}$ and the lowest radiation value was found at sunset $(6$ p.m.) and the radiation value was $190 \mathrm{~W} / \mathrm{m}^{2}$. The external temperature and relative humidity are important factors affecting the poultry house environment. The outdoor temperature affected heat levels inside the houses. The maximum value of the external temperature in June was $33^{\circ} \mathrm{C}$ in the afternoon, with a relative humidity of $47.5 \%$. The lowest temperature recorded in June was $23.1{ }^{\circ} \mathrm{C}$ (Figure 3). The maximum value of the temperature in July was $33.5{ }^{\circ} \mathrm{C}$ and relative humidity was $49.2 \%$. The lowest temperature recorded in July was $23.3^{\circ} \mathrm{C}$ (Figure 3 ).

\section{Internal microclimate}

When measuring the internal temperature and relative humidity, each house should reach the temperature and humidity level appropriate to the need of chicks at different ages. The temperature should gradually decrease as the bird ages. It was found when using a ventilation rate every two minutes, the temperature gradually decreased so that it did not affect chicks' health and thermal burden. As shown in figure 4 , the highest temperature value $\left(33^{\circ} \mathrm{C}\right)$ was recorded when the ventilation rate was every 2 minutes using the conventional system. The temperature continued to decrease to the end of life. In the traditional system, the temperature reached $27.1^{\circ} \mathrm{C}$ while in the solar systems reached $26.3{ }^{\circ} \mathrm{C}$ which was closer to the thermal requirement of the herd according to Arbor Acres (2015).
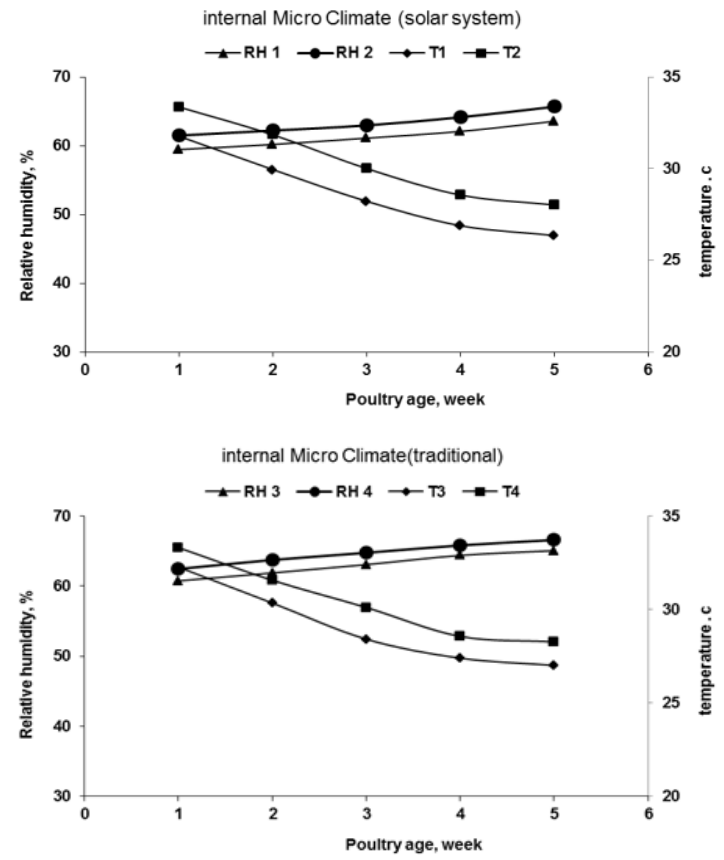

Figure 4. Internal microclimate in experimental poultry houses with the different heating systems located in ElSharkia Governorate, Egypt, during June and July 2018. T1: temperature in house 1, T2: temperature in house 2, T3: temperature in house 3, T4: temperature in house 4. RH 1: relative humidity in house 1, RH 2: relative humidity in house 2, RH 3: relative humidity in house 3, RH 4: relative humidity in house 4. House 1: solar heating system and ventilation rate every 2 min. House 2: traditional heating system and ventilation rate every $2 \mathrm{~min}$. House 3: solar heating system and ventilation rate every $4 \mathrm{~min}$. House 4: traditional heating system and ventilation rate every $4 \mathrm{~min}$. 
In poultry houses with ventilation rate every four minutes with two heating systems, the highest temperature was recorded in house $4\left(33.5{ }^{\circ} \mathrm{C}\right)$. The temperature continued to decrease to the end of life. In the traditional system, it reached $28.1{ }^{\circ} \mathrm{C}$ and in the solar systems reached $27.5{ }^{\circ} \mathrm{C}$. The relative humidity was affected by quantity of air. When the ventilation rate was every 2 minutes, humidity in house 1 was lower than house 2 due to high quantity of air.

\section{Ammonia gas emission}

Ammonia level is an indicator of the quality of the ventilation process. The increased ammonia in the house environment adversely affects poultry health and also causes problems for farm workers (Zong et al., 2014). Figure 5 presents ammonia levels within the houses.
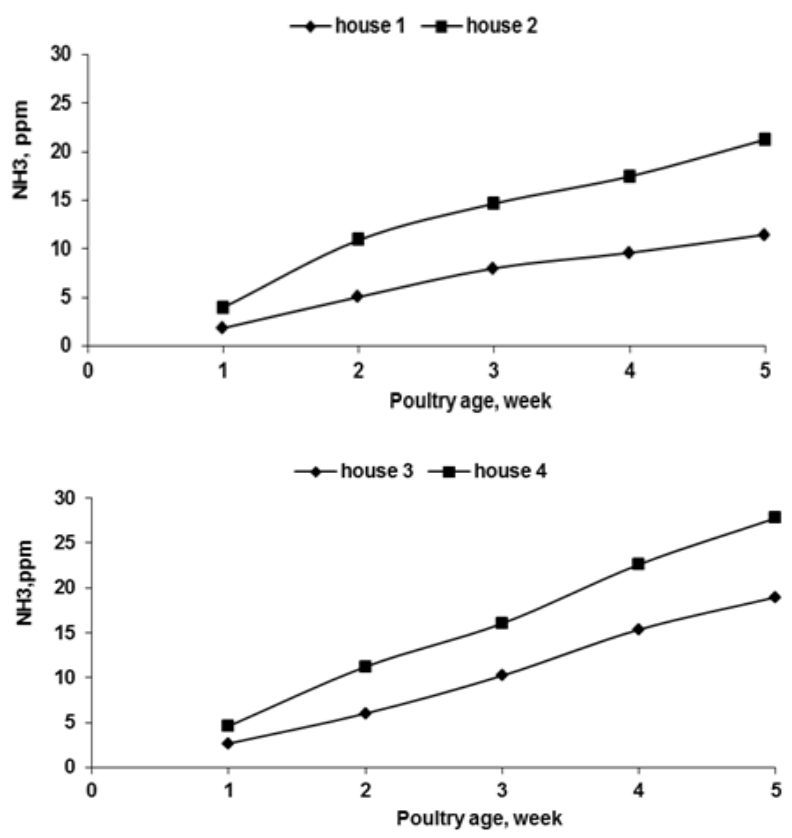

Figure 5. Internal ammonia gas emissions in experimental poultry houses with the different heating systems located in El-Sharkia Governorate, Egypt. House 1: solar heating system and ventilation rate every $2 \mathrm{~min}$. House 2: traditional heating system and ventilation rate every $2 \mathrm{~min}$. House 3: solar heating system and ventilation rate every $4 \mathrm{~min}$. House 4: traditional heating system and ventilation rate every $4 \mathrm{~min}$.

The ammonia levels at the beginning of life were low and gradually increased with age. When using a ventilation rate every two minutes, the average ammonia concentration in the first week was $1.8 \mathrm{ppm}$. Traditional systems led to more ammonia emissions. Emission of ammonia in the solar systems reached $15 \mathrm{ppm}$ while in the conventional system it reached $20 \mathrm{ppm}$. Ammonia concentration with increasing age showed an upward trend in all farms. When the ventilation rate was every four minutes, the level of ammonia in the first week reached to $4 \mathrm{ppm}$. At the end of the rearing cycle, this rate increased up to 20-23 ppm. This finding was similar to the results of Alloui et al. (2013) and Beker et al. (2004). Ammonia concentration in the house with conventional systems and ventilation rate every two minutes, reached higher than 22 ppm while the level of ammonia was $28 \mathrm{ppm}$ in ventilation rate every four minutes.

\section{Ventilation rate and heat loss}

The energy loss was averaged over the duration of ventilation and delivery walls. The energy loss obtained in each experimental house ranged from 0 to $0.5 \mathrm{kWh} / \mathrm{kg}$ and this finding was similar to Rajaniemi (2012). In the summer with the increase of poultry age, the heat in the poultry house was less than outside. The energy loss recorded in each farm ranged from 0 to $0.7 \mathrm{KWh}$ per $\mathrm{kg}$ of live weight that was similar to the results reported by Rajaniemi (2012). As showed in figure 6, the loss of thermal energy was $0.56 \mathrm{kWh}$ for the first week.

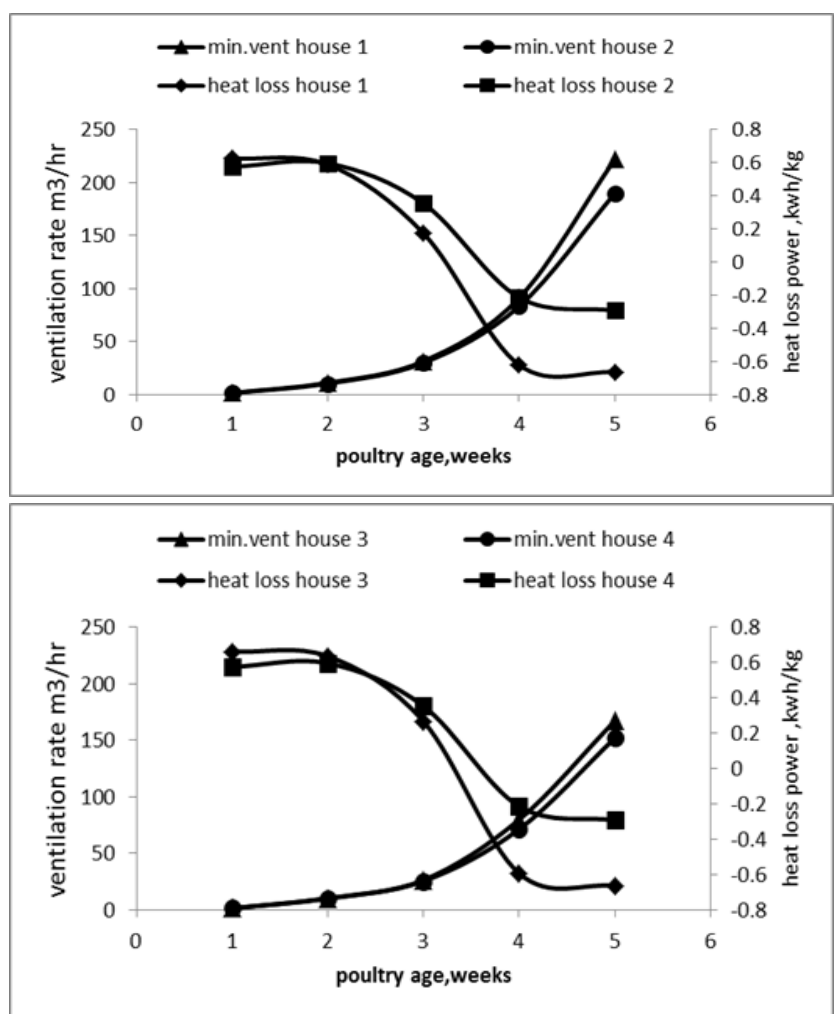

Figure 6. Minimum ventilation rate and heat loss in experimental poultry houses with different heating systems located in El-Sharkia Governorate, Egypt. Min. vent: minimum ventilation rate. House 1: solar heating system and ventilation rate every $2 \mathrm{~min}$. House 2: traditional heating system and ventilation rate every $2 \mathrm{~min}$. House 3: solar heating system and ventilation rate every $4 \mathrm{~min}$. House 4: traditional heating system and ventilation rate every $4 \mathrm{~min}$. 


\section{Poultry weight}

The meat produced from poultry houses at the end of the rearing period varied and provided evidence from the quality of the production process. The highest average weight of meat produced by a chicken was $2.35 \mathrm{~kg}$ when using solar heating system with a ventilation rate every two minutes. It was expected that the high ventilation rate, low levels of ammonia and other toxic gases lead to increased weight. In the summer, ventilation rate every two minutes provided optimum heat and heat elimination resulting in increased production.

In the solar heating system and ventilation rate every four minutes, the weight dropped slightly and reached 2 $\mathrm{kg}$. This decline was due to several reasons; the first reason was the low conversion coefficient caused by pathogens as well as the increase in the average temperature. The second was high thermal pressure in the summer season leading to low productivity.

\section{Solar heating system}

As showed in table 1, the efficiency of the solar heating system was $71.2 \%$ in June. Heat loss in the solar heating system was $9.2 \mathrm{kWh} /$ day, the maximum stored energy value was up to $20.6 \mathrm{kWh} /$ day and the storage efficiency of the solar system was $90.7 \%$. The total efficiency of the solar heating system in July was $70.9 \%$, but the energy loss was $9.8 \mathrm{kWh} /$ day and the energy consumption was $23.8 \mathrm{kWh} /$ day. The solar energy was stored in tanks as hot water $\left(60{ }^{\circ} \mathrm{C}\right)$ with storage efficient up to $91.2 \%$ and the losses were low that was consistent with results reported by Kalogirou (2004).

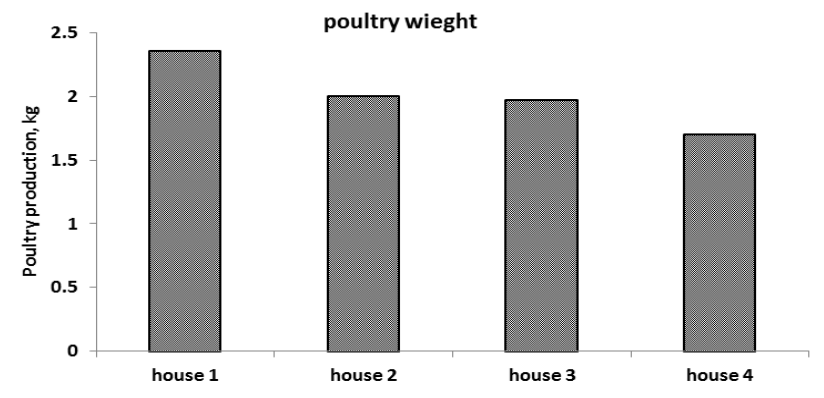

Figure 7. The mean Slaughter weight of birds in experimental poultry houses with different heating systems located in El-Sharkia Governorate, Egypt. House 1: solar heating system and ventilation rate every $2 \mathrm{~min}$. House 2: traditional heating system and ventilation rate every 2 min. House 3 : solar heating system and ventilation rate every $4 \mathrm{~min}$. House 4: traditional heating system and ventilation rate every $4 \mathrm{~min}$.

Table 1. Thermal performance analysis of solar heating system

\begin{tabular}{l|c|c|c|c|c|c|c|c}
\hline \multirow{2}{*}{ Month } & $\mathbf{Q}$ & $\mathbf{Q}_{\mathbf{a}}$ & $\mathbf{F}_{\mathbf{R}}$ & $\mathbf{Q}_{\mathbf{u}}$ & $\mathbf{Q}_{\mathbf{L}}$ & $\boldsymbol{\eta}$ & $\mathbf{Q}_{\mathbf{s}}$ & $\boldsymbol{\eta}_{\mathbf{s}}$ \\
\cline { 2 - 9 } & $\mathbf{K W h} / \mathbf{d a y}$ & $\mathbf{K W h} / \mathbf{d a y}$ & $\mathbf{d e c i m a l}$ & $\mathbf{K W h} / \mathbf{d a y}$ & $\mathbf{K W h} / \mathbf{d a y}$ & $\boldsymbol{\%}$ & $\mathbf{K W h} / \mathbf{d a y}$ & $\mathbf{\%}$ \\
\hline \multirow{2}{*}{ June } & 38.158 & 31.90009 & 0.86 & 22.71624 & 9.183847 & 71.15067 & 20.6 & 90.68402 \\
\multirow{2}{*}{ July } & 40.10232 & 33.52554 & 0.87 & 23.76746 & 9.758085 & 70.8911 & 21.68 & 91.21716 \\
\hline
\end{tabular}

Q: solar energy available, $\mathrm{Q}_{\mathrm{a}}$ : Absorbed solar radiation, $\mathrm{F}_{\mathrm{R}}$ : Heat removal factor, $\mathrm{Q}_{\mathrm{u}}$ : Useful heat gain, $\mathrm{Q}_{\mathrm{L}}$ : Solar heat loss, $\eta$ : Thermal efficiency of solar collector, $Q_{s}$ : Solar energy stored, $\eta_{\mathrm{s}}$ : Storage system efficiency

\section{CONCLUSION}

This study concluded that the use of mechanical ventilation is better than conventional and a ventilation rate every two minutes is highly beneficial. The use of solar energy with electricity as a mixed heating system produces good results.

\section{DECLARATION}

\section{Authors' contributions}

Al authors contributed equally to this study and confirmed the final edition of article.

\section{Competing interests} interests

\section{REFERENCES}

Alloui N, Alloui MN, Bennoune O and Bouhentala S (2013). Effect of ventilation and atmospheric ammonia on the health and performance of broiler chickens in summer. Journal of World's Poultry Research, 3(2): 54-56.

Arbor Acres (2009). Broiler Management Guide, Aviagen.

Arbor Acres (2015). Broiler Management Guide. Available at: www.aviagen.com.

Beker A, Vanhooser SL, Swatzlander JH and Teeter RG (2004). Atmospheric ammonia concentration effects on broiler growth and performance. The Journal of Applied Poultry Research, 13: 5-9. DOI: doi.org/10.1093/japr/13.1.5

Donald JO (2009). Environmental management in the broiler house. Aviagen.

El-Kholy MS, El-Hindawy MM, Alagawany M, Abd El-Hack1 ME and El-Sayed SAA (2017). Dietary supplementation of 
Gad et al., 2019

chromium can alleviate negative impacts of heat stress on performance, carcass yield, and some blood hematology and chemistry indices of growing Japanese quail. Biological Trace Element Research, 179(1): 148-157. DOI: http://dx.doi.org/10.1007/s12011-017-0936-z.

Hamilton J, Negnevitsky M and Wang X (2016). Thermal analysis of a single-storey livestock barn. Advances in Mechanical Engineering, 8(4): 1-9. DOI: https://doi.org/10.1177/1687814016643456

Kalogirou SA (2004). Solar thermal collectors and applications. Progress in Energy and Combustion Science, 30: 231-295. DOI:https://doi.org/10.1016/j.pecs.2004.02.001

Mannfros B and Hautala M (2011). Microclimate in animal houses based on animal welfare: recommendations for ventilation and temperature. Department of Agricultural Sciences publications. University of Helsinki. pp. 102

Rajaniemi M and Ahokas J (2012). A case study of energy consumption measurement system in broiler production. Agronomy Research Biosystem Engineering Special, 1: 195-204.

Tike (2010). Yearbook of Farm Statistics. Agriculture, forestry and fishery. pp. 270

Zong C, Feng Y, Zhang G and Hansen MJ (2014). Effects of different air inlets on indoor air quality and ammonia emission from two experimental fattening pig rooms with partial pit ventilation system-summer condition. Biosystems Engineering, 122: 163-173. DOI: https://doi.org/10.1016/j.biosystemseng.2014.04.005 